\title{
Variation in hepatic aryl hydrocarbon hydroxylase activity in flounder, Platichthys flesus: A baseline study
}

\author{
J. Tarlebø ${ }^{1}$, J. E. Solbakken² \& K. H. Palmork ${ }^{2}$ \\ ${ }^{1}$ Institute of Fisheries Biology, University of Bergen; Nordnesparken 2a, \\ N-5011 Bergen-Nordnes, Norway \\ ${ }^{2}$ Institute of Marine Research, Directorate of Fisheries; Nordnesparken 2, \\ N-5011 Bergen-Nordnes, Norway
}

\begin{abstract}
This investigation is concerned with the natural variations in aryl hydrocarbon hydroxylase (AHH) activity of flounder (Platichthys flesus L.) throughout the year. A general trend towards higher activity in males was observed. It became significant during gonadal maturation, a period during which the activity in females was inhibited. Addition of $\alpha$-naphthoflavone inhibited AHH activity except in females with maturing gonads. Enzyme activity measured at the optimal temperature for incubation showed highest activity during spring followed by a significant decrease during summer. Activity increased again during autumn, followed by a second decrease in the winter season. When activity was calculated based on ambient water temperature at time of sampling, smaller fluctuations between different seasons were observed; the only significant variation was high activity in June. The results obtained indicate that $\mathrm{AHH}$ activity is affected by both exogenous and endogenous factors, which should be taken into consideration if AHH activity is used as a biological indicator of marine pollution effects.
\end{abstract}

\section{INTRODUCTION}

It is now well established that fish have the ability to metabolize various xenobiotics occurring in the aquatic environment. The first metabolic step during this process is mediated by a cytochrome P-450-dependent monooxygenase system (for reviews see Chambers \& Yarbrough, 1976; Zitko, 1980; Stegeman, 1981). Treatment of fish with 3methylcholanthrene (3-MC) and similar compounds elicit an induction of this monooxygenase system that, although there is variation in the response, has some characteristics in common with induction observed in mammals (James \& Bend, 1980; Stegeman, 1981). Several organic pollutants in the marine environment are active as 3-MC-type inducers in fish, including polynuclear aromatic hydrocarbons (PAH) (James \& Bend, 1980), various polyhalogenated biphenyls (Elcombe \& Lech, 1978) and complex mixtures such as petroleum and its refined products (Payne \& Penrose, 1975). The induction of cytochrome P-450 (cyt. P-450) seems to be associated with the synthesis of new or additional microsomal proteins, possibly new cyt. P-450 isoenzyme(s) (Elcombe \& Lech, 1979 ; Stegeman et al., 1981). Williams \& Buhler (1982) have shown that liver of rainbow trout (Salmo gairdneri) contains several different isoenzymes of cyt. P-450.

Payne (1976) found elevated levels of hepatic aryl hydrocarbon hydroxylase (AHH) activity in fish from petroleum-contaminated sites, and suggested that $\mathrm{AHH}$ induction 
could be used as an indicator of petroleum contamination. Field observations by Kurelec et al. (1977), Stegeman (1978) and Walton et al. (1978) have confirmed the induction of $\mathrm{AHH}$ acitivity in fish from polluted areas. In addition, it has been reported that $\alpha$ naphthoflavon (ANF) inhibits AHH activity in microsomes from fish treated with $\mathrm{PAH}_{\text {, }}$ but either do not effect or, in some cases, enhances activity in microsomes from control fish (Kurelec et al., 1981; Bend et al., 1977). It seems therefore likely that ANF-inhibition could be used as an indicator of stress caused by organic contamination (Foureman et al., 1983).

If the monooxygenase system is to be used in monitoring, knowledge of natural variation within the system is necessary (Stegeman, 1980). Koivusaari et al. (1981) have investigated the variation in the monooxygenase system of rainbow trout and found significant differences in activity throughout the year. This investigation was designed as a baseline study on the monooxygenase system of a fish species found in Norwegian fjords. The flounder (Platichthys flesus L.) fulfilled the demands of a stationary, abundant species common in Norwegian coastal waters. Previously, it was shown that the hepatic monooxygenase system in flounders is inducible by organic pollution (unpublished results).

\section{MATERIALS AND METHODS}

\section{Chemicals}

NADP, glucose-6-phosphate, $\alpha$-naphthoflavone, Tris and $B(a) P$ were obtained from Sigma Chemicals Co. (USA). [ $\left.{ }^{14} \mathrm{C}\right] \mathrm{B}(\mathrm{a}) \mathrm{P}(21 \mathrm{mCi} / \mathrm{mmol})$ was obtained from Amersham (England), dye reagent and bovine albumin from Bio Rad Laboratories (USA) and Scint Hei 3 (scintillation cocktail) from Koch Light Laboratories (England). All other chemicals were of analytical grade*.

\section{$\mathrm{B}(\mathrm{a}) \mathrm{P}$ purification}

The $\left({ }^{14} \mathrm{C}\right) \mathrm{B}(\mathrm{a}) \mathrm{P}$ was diluted with unlabelled $\mathrm{B}(\mathrm{a}) \mathrm{P}$ and purified according to the method described by Van Cantford et al. (1977),

\section{Fish capture and treatment}

Flounder (Platichthys flesus) were caught by beach seine at Sotra, an island southwest of Bergen (Norway). This is an area with no known sources of organic contamination. Fish were collected at the same location at two-month intervals from February 1982 to April 1983.

Maximally $3 \mathrm{~h}$ after sampling, fish were stunned with a blow on the head, the gall bladders were carefully removed and the livers were excised and placed in liquid nitrogen. Livers were transported to the laboratory in liquid nitrogen and stored at $-80^{\circ} \mathrm{C}$.

- Abbreviations used in this paper: AHH: aryl hydrocarbon hydroxylase, ANF: $\alpha$-naphthoflavone, cyt. P-450: cytochrome P-450, PMS: postmitochrondrial supernatants 


\section{Tissue preparation and analysis}

The livers were thawed in ice-cold $1.15 \% \mathrm{KCl}$. We found that enzyme activity drops by approximately $20 \%$ due to the freezing and thawing procedure. No livers were stored more than 3 months, and the drop in activity did not increase during this period. Individual livers were homogenized in a teflon-glass homogenizer with three volumes of $1.15 \% \mathrm{KCl}$. The homogenates were centrifuged at $10000 \times \mathrm{g}$ for $10 \mathrm{~min}$ (Sigma $2 \mathrm{MK}$ centrifuge), and the resulting postmitochondrial supernatants (PMS) were utilized in the incubation. All steps were performed at $0-4{ }^{\circ} \mathrm{C}$.

The enzyme assay was a slight modification of the method described by Van Cantford et al. (1977). The reaction mixture contained: $0.40 \mathrm{mM}$ NADP, $2.5 \mathrm{mM}$ glucose6-phosphate, $50 \mathrm{mM}$ Tris buffer ( $\mathrm{pH} 7.4$ ), $5 \mathrm{mM} \mathrm{Mg} \mathrm{Cl}, 0.08 \mathrm{mM}$ B(a)P dissolved in $10 \mu \mathrm{l}$ of acetone and PMS (4-5 mg protein $/ \mathrm{ml})$ in a total volume of $0.5 \mathrm{ml}$. The mixture was incubated $15 \mathrm{~min}$ at $30^{\circ} \mathrm{C}$ which was the optimal temperature for this assay. The reaction was linear with time, and over the ranges of protein concentration utilized.

The influence of $\alpha$-naphthoflavone (ANF) on B(a)P-metabolism was determined by adding $0.1 \mathrm{mM}$ ANF in $10 \mu \mathrm{l}$ acetone prior to the addition of $\mathrm{B}(\mathrm{a}) \mathrm{P}$.

The samples were analysed using a Packard $300 \mathrm{CD}$ liquid scintillation counter with an automatic quench corrector system.

Protein concentration was determined according to Bradford (1976) using bovine serum albumin as standard.

\section{Enzyme activity - presentation}

Enzyme activity (Ea) is presented normalized to liver somatic index (LSI, liver weight $\times 100$ /body weight):

$$
\mathrm{Ea}=\frac{\text { Mole of } \mathrm{B}(\mathrm{a}) \mathrm{P} \text { metabolized } \times \text { LSI }}{15(\text { min for the reaction }) \times \mathrm{g} \text { liver in the reaction }}
$$

This equation is established to relate enzyme activity to accumulation and elimination of xenobiotics. Body weight gives some indication of the amount of xenobiotics a fish may accumulate, whereas liver weight is an important parameter in determining the total hepatic enzyme activity and thereby the elimination of xenobiotics.

Fishes are poikilothermic organisms, and they are sensitive to variations in the environmental temperature. We wanted therefore to calculate what the enzyme activity would be if the incubation was performed at the sea temperature measured during sampling. The relationship between incubation temperature and enzyme activity was established in one sample, and this relationship was used to calculate the activity at environmental temperatures in the other samples.

\section{Statistics}

Analysis of variance and Newman-Keuls procedure for multiple range testing were used to test differences between pairs of means of the same sex. Students $t$-test was performed for testing of sex differences. These statistical procedures are described in ZAR (1974). In all tests the level of significance was set at $P<0.05$. 


\section{RESULTS}

As indicated in Table 1, fish were sampled over a period of more than one year. Samples containing individuals with maturing gonads were divided into groups of males, females and juveniles. Statistical analysis showed no significant difference between juveniles and males, and these two groups were therefore combined. In samples without maturing individuals we only distinguished between males and females. An exception is the sample taken July 1982, where we considered all the individuals as one group due to the small sample size.

The maturation of the gonads started in October/November, and the flounders spawned in February/March. There was a statistically significant increase in liver somatic index (LSI) in females containing maturing gonads, and in both female and

Table 1. Dates of sampling, sea temperature, total body weight, LSI, condition factor and PMS protein in Platichthys flesus (mean \pm standard deviation)

\begin{tabular}{|c|c|c|c|c|c|c|c|}
\hline \multirow[t]{2}{*}{$\begin{array}{l}\text { Sampling } \\
\text { dates }\end{array}$} & \multirow{2}{*}{$\begin{array}{c}\text { Sea } \\
\text { tem- } \\
\text { perature } \\
\left({ }^{\circ} \mathrm{C}\right)\end{array}$} & \multirow{2}{*}{$\begin{array}{c}\text { Body } \\
\text { weight } \\
\text { (g) }\end{array}$} & \multicolumn{2}{|c|}{ LSI } & \multicolumn{2}{|c|}{$\begin{array}{l}\text { Condition } \\
\text { factor }\end{array}$} & \multirow{2}{*}{$\begin{array}{l}\text { mg PMS } \\
\text { protein } \\
\text { g liver }\end{array}$} \\
\hline & & & $q$ & 8 & q & $\%$ & \\
\hline 8. 2.82 & 5.0 & $139.2 \pm 15.2$ & - & $1.1 \pm 0.3$ & - & 1.07 & $46.4 \pm 6.4$ \\
\hline 15. 4.82 & 6.0 & $169.3 \pm 39.5$ & $1.3 \pm 0.2$ & $1.4 \pm 0.2$ & 1.07 & 1.07 & $62.4 \pm 8.0$ \\
\hline 3. 6.82 & 13.5 & $149.0 \pm 75.0$ & $1.3 \pm 0.1$ & $1.3 \pm 0.2$ & 1.16 & 1.10 & $62.4 \pm 8.0$ \\
\hline 30.7 .82 & 15.0 & $137.0 \pm 118.5$ & $1.3 \pm$ & $0.3^{\circ}$ & & & $64.0 \pm 8.0$ \\
\hline 6.10 .82 & 12.7 & $133.0 \pm 61.0$ & $1.1 \pm 0.1$ & $1.2 \pm 0.2$ & 1.06 & 1.11 & $76.8 \pm 11.2$ \\
\hline 6. 12.82 & 8.5 & $186.6 \pm 67.0$ & $2.3 \pm 0.2$ & $1.2 \pm 0.2$ & 1.10 & 1.03 & $76.8 \pm 8.0$ \\
\hline 31. 1.83 & 5.7 & $226.8 \pm 107.5$ & $1.7 \pm 0.5$ & $1.1 \pm 0.1$ & 1.09 & 1.08 & $68.8 \pm 11.2$ \\
\hline 7. 4.83 & 5.9 & $157.2 \pm 69.6$ & $1.7 \pm 0.5$ & $1.6 \pm 0.3$ & 1.11 & 1.06 & $67.2 \pm 11.2$ \\
\hline
\end{tabular}

males from April 1983 (Table 1). There was no significant difference in the condition factor (weight $\times 100 /$ length $^{3}$ ) throughout the year. The PMS protein content per gram liver was very low in fish sampled February 1982, whereas it appeared to be above average in fish from October and December 1982 (Table 1).

\section{Variation with size}

Data from samples taken April, June and October 1982 and April 1983 were used to test for correlation between enzyme activity and body-liver weight, LSI and condition factor. These samples were used since the differences in enzyme activity within and between them were small, and the size range found in these samples were the same as that of all the flounders. No significant correlations were found (Table 2). Differing size range within samples will therefore not be of importance in the further treatment of the data. 
Table 2. Correlation coefficients between AHH activity and body-liver weight, LSI and condition factor

\begin{tabular}{|lccc|}
\hline Variables & $\begin{array}{c}\text { Specific } \\
\text { activity }\end{array}$ & $\begin{array}{c}\text { Activity normal } \\
\text { to LSI }\end{array}$ & Range \\
\hline Body weight & -0.10 & -0.11 & $52.5 \mathrm{~g}-323.5 \mathrm{~g}$ \\
Liver weight & -0.18 & -0.03 & $0.8 \mathrm{~g}-7.3 \mathrm{~g}$ \\
LSI & -0.15 & -0.17 & $0.9-2.3$ \\
Condition factor & -0.12 & -0.07 & $0.9-1.4$ \\
\hline
\end{tabular}

\section{Variation between sexes}

Figs $1 \mathrm{a}$ and $1 \mathrm{~b}$ show the variations in enzyme activity throughout the sampling period. These data indicate that male flounders generally had higher AHH activity than females, and that this tendency became significant when the flounders contained maturing gonads.

The addition of ANF inhibited the enzyme activity in all flounders except females with maturing gonads, in which activity was nearly unaffected by ANF (Table 3). AHH activity was inhibited to the same extent in fishes with relatively low (July 1982) and high (April 1983) activity (Table 3).

Table 3. Effects of administration of ANF on enzyme activity. The activity measured with addition of ANF is called 'remaining activity'

\begin{tabular}{|c|c|c|c|c|}
\hline \multirow[t]{2}{*}{ Date } & \multirow[t]{2}{*}{ Sex } & \multirow{2}{*}{$\begin{array}{l}\text { Specific activity } \\
(\mathrm{pmol} / \mathrm{min} / \mathrm{mg})\end{array}$} & \multicolumn{2}{|c|}{ Remaining activity } \\
\hline & & & $\mathrm{pmol} / \mathrm{min} / \mathrm{mg}$ & $\%$ \\
\hline 30. 7.82 & $q$ & $93.7 \pm 68.8$ & 29.2 & 38.6 \\
\hline 6. 10.82 & ¿ & $172.1 \pm 60.0$ & 65.2 & 41.0 \\
\hline 6.10 .82 & \& & $131.8 \pm 57.6$ & 57.6 & 45.8 \\
\hline 6. 12.82 & $\delta$ & $100.4 \pm 16.9$ & 50.0 & 52.5 \\
\hline 6. 12.82 & $q$ & $21.0 \pm 14.2$ & 21.4 & 102.4 \\
\hline 7. 4.83 & a & $175.2 \pm 77.0$ & 57.6 & 33.6 \\
\hline 7. 4.83 & $q$ & $129.3 \pm 65.7$ & 45.8 & 37.2 \\
\hline \multicolumn{5}{|c|}{ " Remaining activity $\times 100$} \\
\hline Specif & & & & \\
\hline
\end{tabular}

\section{Seasonal variations}

The AHH activity in male fishes had its maximum during spring followed by a significant decrease in activity during summer (Figs 1a and 1b). In autumn we observed a significant increase in activity, followed by a second drop appearing in the winter season. The decrease in activity observed during winter seemed mainly to be related to that portion of $\mathrm{AHH}$ activity inhibited by ANF, whereas the decrease in the noninhibited portion was less pronounced (Table 3). 
The activity in females followed the same pattern, with the exception of the above mentioned decrease in females containing developing gonads. The increase in activity during the autumn was no longer significant.

The seasonal variations were very much alike for both specific activity and activity normalized to LSI (Figs 1a and 1b). The only large difference was found in fish sampled in February 1982, which had a rather high specific activity compared with normalized activity. This was probably due to the very low protein content in the PMS-fraction of these fishes (Table 1).
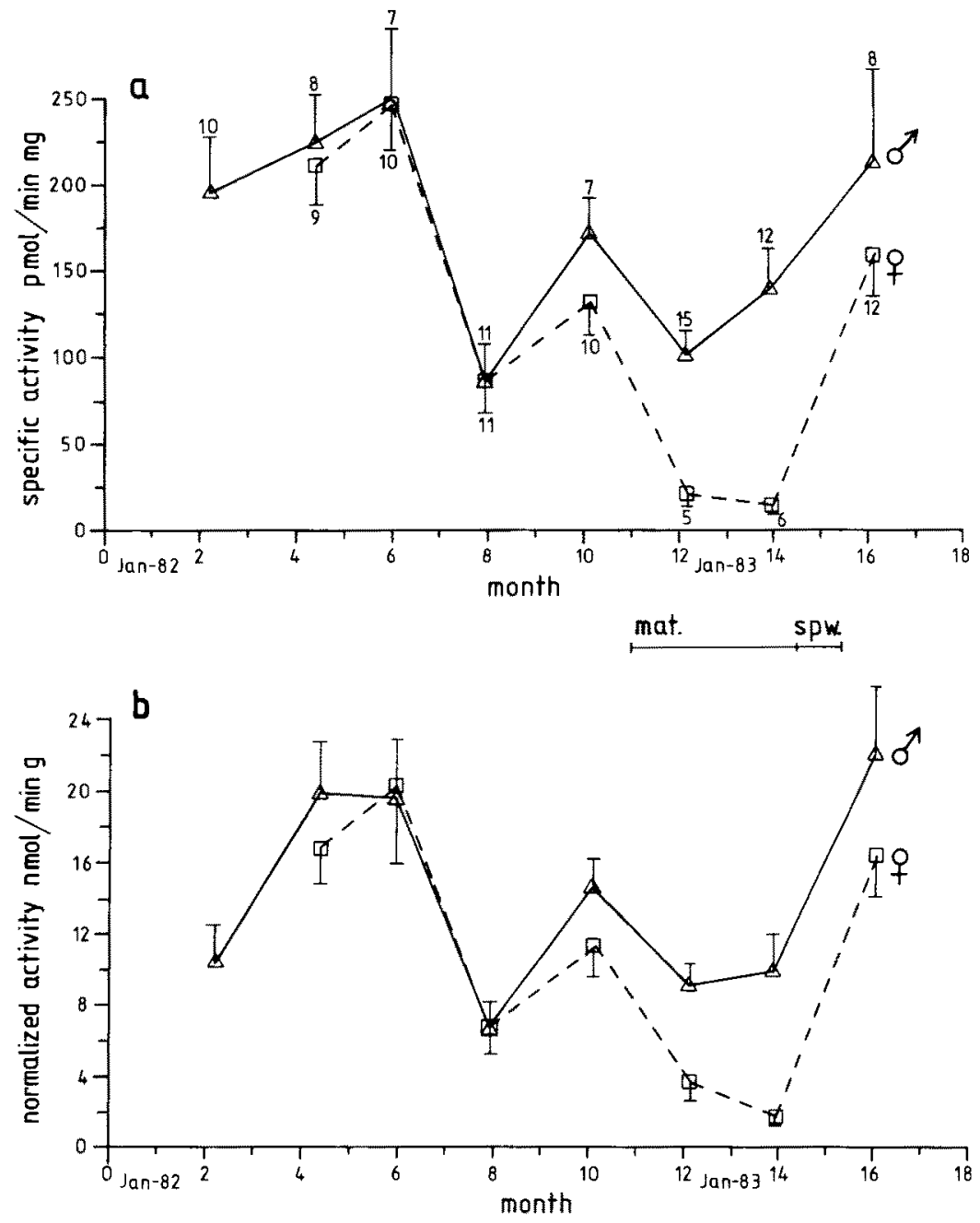

Fig. 1a, b. Variation in aryl hydrocarbon hydroxylase in Platichthys flesus. Specific activity is expressed as picomoles metabolites formed per min per mg proteins, normalized activity (see text). Note the different scaling of the $y$-axes. The bars show the standard error of the means $(n=5-15)$. Mat.: period of gonadal maturation. Spw.: period of spawning. $a$ and $b$ : enzyme activity measured at incubation temperature of $30^{\circ} \mathrm{C}$ 
Fishes are poikilothermic animals which means that their monooxygenase system does not function at a specific temperature, but has to adapt to a range of temperatures. Therefore, the relationship between in vitro incubation temperature and enzyme activity, obtained with liver from fish captured April 1981, was studied. Based on the assumptions that this relationship is constant throughout the year and that it reflects the relationship between enzyme activity and water temperature, the activity at the observed sea temperatures was calculated. The results are shown in Figs $1 \mathrm{c}$ and $1 \mathrm{~d}$. The AHH activity in males sampled in June was significantly higher than activity in all other samples. This was due to high activity rates measured at $30^{\circ} \mathrm{C}$ combined with high environmental temperature $\left(13.5^{\circ} \mathrm{C}\right)$. In all other samples there was a trend towards lower variations in activity between different seasons, and none of these variations were significant.

The enzyme activity in females followed the same pattern, but again with the addition of a significant decrease in females with developing gonads.
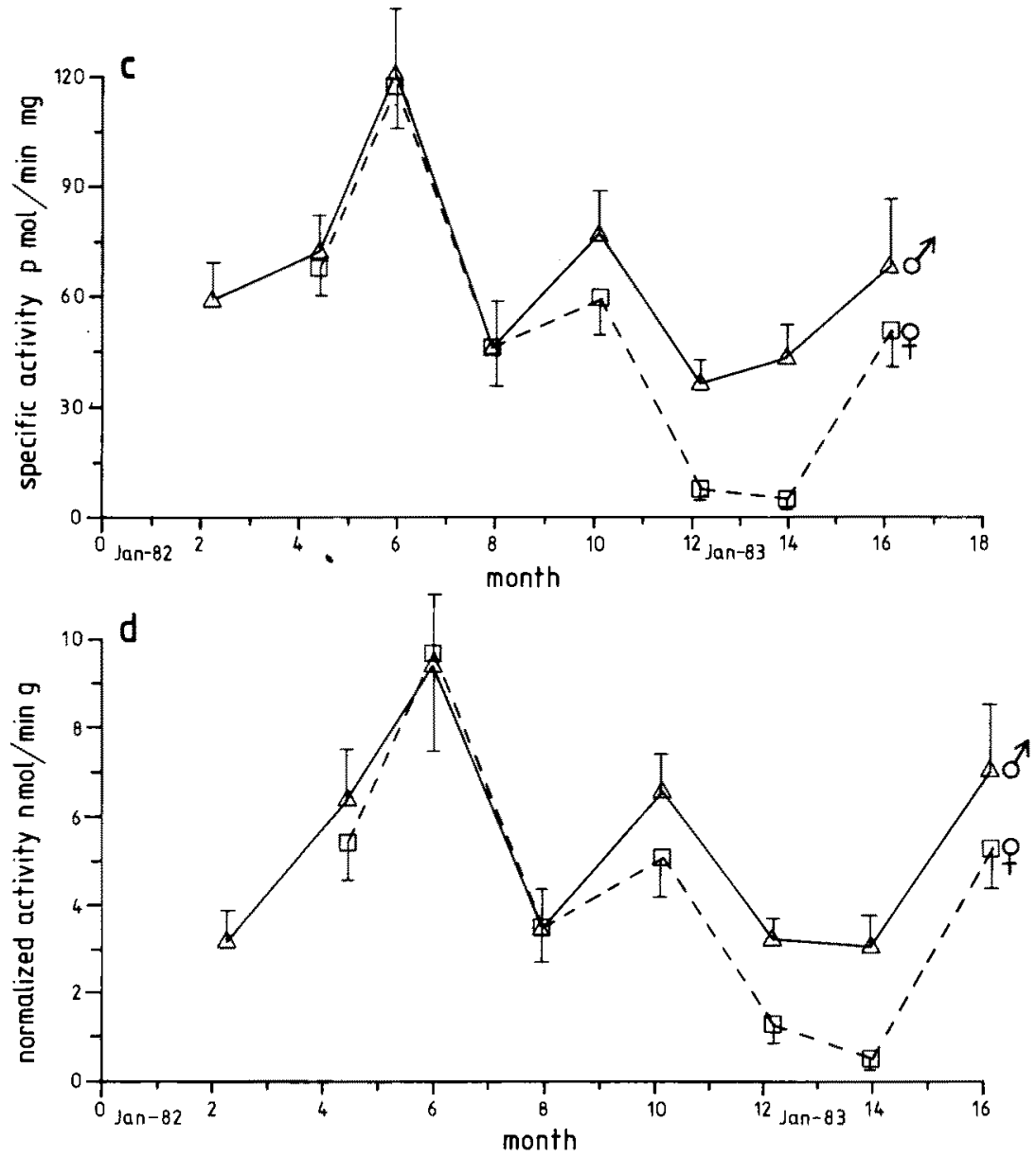

Fig. 1c, d. Variation in AHH activity in flounder. Enzyme activity corrected to the environmental temperature (see text) 


\section{DISCUSSION}

The present results indicate that $\mathrm{AHH}$ activity in flounder varies considerably during the year. The activity is affected by both endogenous (gonadal maturation) and exogenous (temperature) factors.

In female fish there is a significant increase in liver weight appearing at the onset of gonadal maturation. This is probably related to the reproductive function of the liver as a synthesizing and storing organ of energy-rich substances (Plack \& Fraser, 1971; Van Bohemen et al., 1981). Egaas \& Varanasi (1981) and Dewaide (1970) found a significant increase in liver weight in fish acclimated to cold versus warm water. This is probably not the reason for the observed increase in liver weight from fish collected in April 1983, since such an increase has not been observed in any other cold-water sample. The lack of variation in the condition factor seems to indicate that the flounders were not starved at any part of the year. The observed difference in enzyme activity is therefore not a result of starvation.

The results (Table 2) showed no correlation between enzyme activity and body-liver weight, LSI or condition factor. These findings are in accordance with the results of Walton et al. (1978) and Spies et al. (1982) in experiments using cunner (Tautogolabrus adspersus) and California flatfishes, respectively; whereas Stegeman (1978) reported a significant correlation between body weight and activity normalized to body weight in mummichog (Fundulus heteroclitus).

The present results revealed a tendency towards male flounders having higher enzyme activity than females. This tendency was not significant until the gonadal maturation started, a period in which the AHH-activity of the females dropped to a level significantly lower than in males. This is similar to the results obtained by Walton et al. (1978) on cunner, Stegeman (1980) on winter flounder (Pseudopleuronectes americanus), and Koivusaari et al. (1981) on rainbow trout (Salmo gairdneri). Contrary to these findings is the lack of difference observed in spawning and non-spawning sheepshead (Archosargus probatocephalus) (James \& Little, 1981). Later investigations have shown the decrease in activity and cyt. P-450 content in female rainbow trout to be due to inhibition by a major plasma oestrogen, oestradiol-17 $\beta$ (for review, see Hansson et al., 1982). Stegeman et al. (1982) showed that the effect of oestradiol-17 $\beta$ was to reduce the amount of several proteins, among them possibly one isoenzyme of cytochrome P-450. The results in the present study also showed that the isoenzyme pattern in females with maturing gonads differed from the pattern in other flounders; maturing females did not contain isoenzymes that were inhibited by ANF whereas the rest of the flounders did (Table 3). This indicates a similar inhibition of isoenzyme(s) as Stegeman and his coworkers reported.

AHH-activity was inhibited by ANF, an inhibition that was lost after 14 days in the laboratory (unpubl. results). This could indicate that the monooxygenase system was induced. The activity was, however, inhibited to the same extent in fishes with relatively low and high activity levels. It is therefore possible that the induction is the natural state of the monooxygenase system under natural conditions, and might not be due to pollutants. This induction could be caused by naturally occurring compounds, such as flavenoids found in sea grasses (McMillan et al., 1980), or by other environmental factors. Controversial data is available on the effect of ANF on AHH activity. In some studies, ANF is reported to inhibit activity in microsomes from induced fish, but to have 
no effect or enhance activity in microsomes from control fish (Kurelec et al., 1981; Bend et al., 1977; Foureman et al., 1983); while others have found that ANF inhibits AHH activity in microsomes from both control and induced fish (Elcombe \& Lech, 1979; Schwen \& Mannering, 1982; Stegeman et al., 1981). Further investigations are therefore necessary before inhibition of AHH activity by ANF is accepted as an indication of stress caused by pollutants.

The results obtained in the present study indicate that enzyme activity varies considerably between seasons. When activity was measured at $30^{\circ} \mathrm{C}$, the flounders from July had significantly lower hepatic $\mathrm{AHH}$ activity than flounder sampled during spring and autumn (males), whereas only flounders sampled in June were significantly different from the July-sample if activity was calculated at environmental temperature. This result is the same as that of Dewaide (1970) and Egaas \& Varanasi (1982) who found that enzyme activity was higher in cold-acclimated fish as compared to warm-acclimated fish when measured at an optimal temperature. Likewise, Koivusaari et al. (1981) observed in a field study of rainbow trout the same decrease in activity during summer, a decrease which is much smaller if enzyme activities were measured at environmental temperatures. Contrary to this is the finding of Dewaide \& Henderson (1970) and Spies et al. (1982) that enzyme activity in field samples of roach (Leuciscus rutilus) and California flatfishes, respectively, reaches its maximum in summer. There is, however, in both these investigations the possibility of increased pollution during summer, so that high activity can be due to induction of the monooxygenase system.

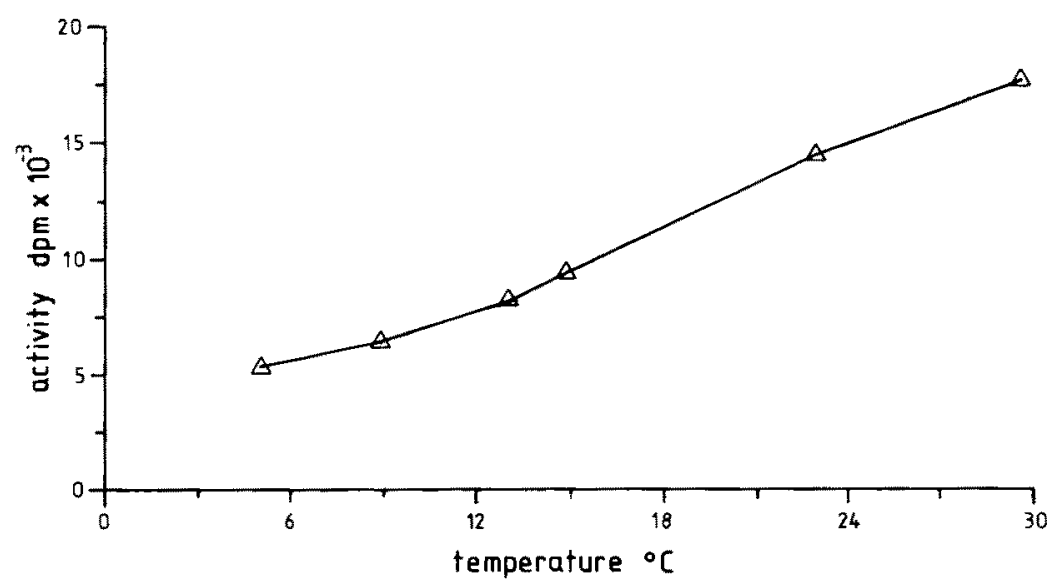

Fig. 2. Relationship between aryl hydrocarbon hydroxylase activity and incubation temperature in liver of flounders (caught in April 1982). The activity is given as disintegrations per min (dpm) of total metabolites of $\mathrm{B}(\mathrm{a}) \mathrm{P}$

As mentioned above, flounders sampled in July had significantly lower enzyme activity than flounders caught in April or October when activity was measured at $30^{\circ} \mathrm{C}$, whereas these differences diminshed if the activity was calculated at environmental temperature. This was due to the observed relationship between in vitro incubation temperature and activity (Fig. 2) which showed that the calculated enzyme activity at the water temperature in July $\left(15^{\circ} \mathrm{C}\right)$ was $53 \%$ of the activity measured at $30^{\circ} \mathrm{C}$, whereas 
the values for April $\left(6^{\circ} \mathrm{C}\right)$ and October $\left(12.7^{\circ} \mathrm{C}\right)$ were 32 and $45 \%$, respectively. The reduction in variation between these groups indicates that the hepatic monooxygenase system in flounder compensates for changing temperatures. A large number of enzymes in poikilothermic animals exhibit compensatory patterns of catalytic activity during thermal acclimation (for review, see Hazel \& Prosser, 1974). This compensation may be achieved by increasing the concentration of key enzymes, generating new isoenzymes and/or altering the microenvironment within which enzymes function. All of these adaptions require a relatively long period of time. Koivussaari (1983) found temperature compensation in the monooxygenase system of rainbow trout; activity was the same in fish sampled in cold and warm water when measured at environmental temperature. This compensation was not due to changes in the total amount of cyt. P-450, which was constant for the two groups. On the other hand, Chambers \& Yarbrough (1979) found highest cyt. P-450 content in winter and lowest in summer in a freshwater species, Gambusia affinis. It therefore appears that species-specific differences may influence the response of fish to changing temperatures.

The enzyme activity in the flounders sampled in June did not fit into this pattern of temperature compensation. A possible explanation for this can be found from the observations of the sea temperature in the Sotra area (Fig. 3). These temperatures were measured on the eastern side of the island, whereas the flounders were sampled on the western side. The temperature shown in Figure 3 therefore only gives an estimate of the

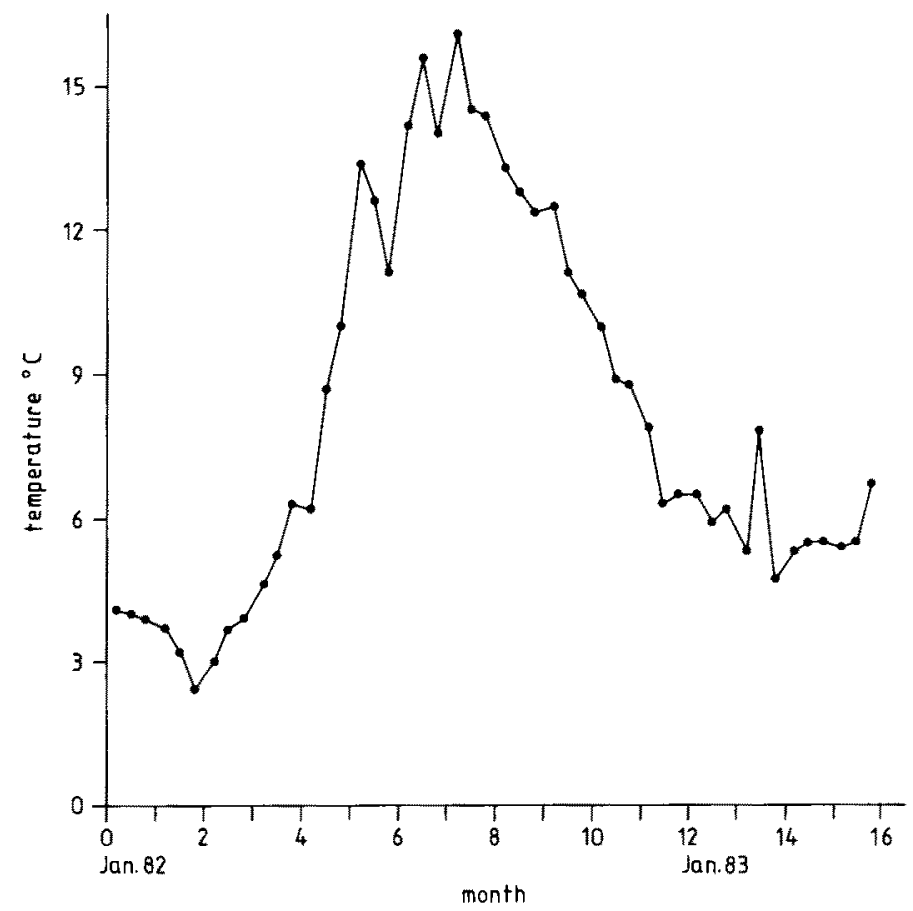

Fig. 3. Sea temperature in the Sotra area measured from January 1982 to May 1983. Temperature was taken daily, and each point represents the mean of 10 daily measurements. (Published with permission of A/S MOWI, Norway) 
actual sea temperature at the sampling site, and the variations between these two sites is indicated by the differences found in Table 1 and Figure 3 . The main difference is that ice covered the sampling site during parts of the winter period, so that the temperature did not drop to the low level found on the eastern side. What Figure 3 clearly shows is that the sea temperature in the Sotra area increased rapidly from May to June. A possible explanation for the high activity in June may therefore be that the monooxygenase system did not have enough time to adapt to this variation in temperature. This means that an effective cold-adapted metabolism was functioning at high temperatures, creating a very efficient combination. In July, the system had adapted to the new temperature range, possibly by decreasing the amount of cyt. P-450 or by some other unknown mechanism(s) which decreased the activity.

The decrease in $\mathrm{AHH}$ activity observed in males and juveniles during the winter, seems mainly to be a reduction in the inducible portion of the activity. This may be a result of lower levels of inducible compounds during winter, or it may be bound to other exogenous and/or endogenous factors.

\section{CONCLUSION}

Many attempts to relate physiological criteria to pollution-induced stress phenomena in aquatic animals have failed. In our opinion, this is in part due to the lack of knowledge on natural variations of the parameters considered. The present study on variation in hepatic aryl hydrocarbon hydroxylase activity demonstrates that several factors must be taken into account. As indicated above, the use of AHH activity in flounder as a biological indicator of marine contamination has the following implications:

(1) Size selection when sampling is not of critical importance. This is true within the size range we have studied, but it must be investigated again if flounder outside this size range is sampled.

(2) Females should be rejected from samples during the time of maturation and spawning. Even after spawning, the optimal sampling procedure would be to choose one sex only; the present results revealed that males are much better suited than females for this kind of investigation.

(3) Enzyme activity should be measured both at the optimal and environmental temperature.

(4) Variations in water temperature will affect the enzyme activity level; sampling should therefore be carried out when the sea temperature is relatively stable.

If these implications are considered, there will probably be periods of the year when $\mathrm{AHH}$ activity cannot be used in monitoring. On the other hand, a sampling procedure following these directives should reduce the variation between individuals of the same species, and thereby increase the possibilities of discovering differences between noninduced and induced groups.

\section{LITERATURE CITED}

Bend, J. R., James, M. O. \& Dansette, P. M., 1977. In vitro metabolism of xenobiotics in some marine animals. - Ann. N. Y. Acad. Sci. 298, 505-521.

Bohemen, Ch. G. van, Lambert, J. G. D. \& Peute, J, 1981. Annual changes in plasma and liver in 
relation to vitellogenesis in the female rainbow trout, Salmo gairdneri. - Gen. comp. Endocrinol. 44, 94-107.

Bradford, M. M., 1976. A rapid and sensitive method for the quantitation of microgram quantities of protein utilizing the principle of protein-dye binding. - Analyt. Biochem. 72, 248-254.

Cantford, J. van, DeGraeve, J. \& Gielen, J. E., 1977. Radio-active assay for aryl hydrocarbon hydroxylase. Improved method and biological importance, - Biochem. biophys. Res. Comm. 79, 505-512.

Chambers, J. E. \& Yarbrough, J. D., 1976. Xenobiotic biotransformation systems in fishes. - Comp. Biochem. Physiol. 55C, 77-84.

Chambers, J. E. \& Yarbrough, J. D., 1979. A seasonal study of microsomal mixed-function oxidase components in insecticide-resistant and susceptible mosquitofish, Gambusia affinis. - Toxic. appl. Pharmac. 48,497-507.

Dewaide, J. H., 1970. Species differences in hepatic drug oxidation in mammals and fishes in relation to thermal acclimation. - Comp. gen. Pharmac. 1, 375-384.

Dewaide, J. H. \& Henderson, P. T., 1970. Seasonal variation of hepatic drug metabolism in the roach, Lenciscus rutilus L. - Comp. Biochem. Physiol. 32, 489-497.

Egaas, E. \& Varanasi, U., 1982. Effects of polychlorinated biphenyls and environmental temperature on in vitro formation of benzo(a)pyrene metabolites by liver of trout (Salmo gairdneri). Biochem. Pharmac. 31 (4), 561-566.

Elcombe, C. R. \& Lech, J. J., 1978. Induction of mono-oxygenation in rainbow trout by polybrominated biphenyls: A comparative study. - Environ. Health Perspect. 23, 309-314.

Elcombe, C. R. \& Lech, J. J., 1979. Induction and characterization of hemoprotein(s) P-450 and mono-oxygenation in rainbow trout (Salmo gairdneri). - Toxic. appl. Pharmac. 49, 437-450.

Foureman, G. L., White Jr., N. B. \& Bend, J. R., 1983. Biochemical evidence that winter flounder (Pseudopleuronectes americanus) have induced hepatic cytochrome P-450-dependent monooxygenase activities. - Can. J. Fish. aquat. Sci. 40, 854-865.

Hansson, T., Forlin, L., Rafter, J. \& Gustafsson, J.-A., 1982. Regulation of hepatic steroid and xenobiotic metabolism in fish. In: Cytochrome P-450, biochemistry, biophysics and environmental implications. Ed. by E. Hietanen, M. Laitinen \& O. Hänninen. Elsevier Biomedical, Amsterdam, 217-224.

Hazel, J. R. \& Prosser, C. L., 1974. Molecular mechanisms of temperature compensation in poikilotherms. - Physiol. Rev. 54,620-677.

James, M. O. \& Bend, J. R., 1980. Polycyclic aromatic hydrocarbon induction of cytochrome P-450dependent mixed-function oxidases in marine fish. - Toxic. appl. Pharmac. 54, 177-133.

James, M. O. \& Little, J., 1981. Polyhalogenated biphenyls and phenobarbital: Evaluation as inducers of drug metabolizing enzymes in the sheepshead, Archosargus probatocephalus. Chemico-biol. Interactions $36,229-248$.

Koivusaari, U., Harri, M. \& Hänninen, O., 1981. Seasonal variation of hepatic biotransformation in female and male rainbow trout (Salmo gairdneri). - Comp. Biochem. Physiol. 70C, 149-157.

Koivusaari, U., 1983. Thermal acclimatization of hepatic polysubstrate monooxygenase and UDPglucuronosyltransferase of mature rainbow trout (Salmo gairdneri). - J. exp. Zool. 227, 35-42.

Kurelec, B., Britvic, S., Rijavec, M., Muller, W. E. G. \& Zahn, R. K., 1977. Benzo(a)pyrene monooxygenase induction in marine fish-molecular response to oil pollution. - Mar. Biol. 44, 211-216.

Kurelec, B., Protic, M., Britvic, S., Kezic, N., Rijavec, M. \& Zahn, R. K., 1981. Toxic effects in físh and the mutagenic capacity of water from the Sava river in Yugoslavia. - Bull, environ. Contam. Toxicol. 26, 179-187.

McMillan, C., Zapata, O. \& Escobar, L., 1980. Sulphated phenolic compounds in seagrasses. Aquat. Bot. 8, 267-278.

Payne, J. F, 1976. Field evaluation of benzopyrene hydroxylase induction as a monitor for marine petroleum pollution. - Science, N. Y. 191, 945-946.

Payne, J. F. \& Penrose, W. R., 1975. Induction of aryl hydrocarbon (Benzo(a)pyrene) hydroxylase in fish by petroleum. - Bull. environ. Contam. Toxicol. 14, 112-116.

Plack, P. A. \& Fraser, N. W., 1971. Incorporation of L- $\left[{ }^{14} \mathrm{C}\right]$ Leuxine into egg protein by liver slices from cod. - Biochem. J. 121, 857-862.

Schwen, R. S. \& Mannering, G. J., 1982. Hepatic cytochrome P-450-dependent mono-oxygenase 
systems of the trout, frog and snake. II. Mono-oxygenase activities. - Comp. Biochem. Physiol. $71 B, 437-443$.

Spies, R. B., Felton, J. S. \& Dillard, L., 1982. Hepatic mixed-function oxidases in California flatfishes are increased in contaminated environments and by oil and PCB ingestion. - Mar. Biol, 70 , $117-127$.

Stegeman, J. J., 1978. Influence of environmental contamination on cytochrome P-450 mixedfunction oxygenase in fish: Implications for recovery in the Wild Harbor Marsh. - J. Fish, Res. Bd Can. 35, 668-674.

Stegeman, J. J., 1980. Mixed function oxygenase studies in monitoring for effects of organic pollution. - Rapp. P.-v. Réun. Cons. int. Explor. Mer. 179, 33-38.

Stegeman, J. J., 1981. Polynuclear aromatic hydrocarbons and their metabolism in the marine environment. In: Polycyclic hydrocarbons and cancer. Ed. by $\mathrm{H}$. V. Gelboin \& P. O. P. Ts' O. Acad. Press, New York, 3, 1-60.

Stegeman, J. J., Klotz, A. V., Woodin, B. R. \& Pasor, A. M., 1981. Induction of hepatic cytochrome P450 in fish and the indication of environmental induction in scup (Stenotomus chrysops). Aquat. Toxicol. 1, 197-212.

Stegeman, J. J., Pasor, A. M. \& Thomas, P., 1982. Influence of estradiol and testosterone on cytochrome P-450 and monooxygenase activity in immature brook trout, Salvelinus fontinalis. Biochem. Pharmac. 31, 3979-3989.

Walton, D. G., Penrose, W. R. \& Green, J. M., 1978. The petroleum-inducible mixed-function oxidase of cunner (Tautolabrus adspersus Walbaum 1792): Some characteristics relevant to hydrocarbon monitoring. - J. Fish. Res. Bd Can. 35, 1547-1552.

Williams, D. E. \& Buhler, D. R., 1982. Purification of cytochromes P-448 from $\beta$-naphthoflavonetreated rainbow trout. - Biochem. biophys. Acta 717, 398-404.

Zar, J. H., 1974. Biostatistical analysis. Prentice-Hall Inc., Englewood Cliffs, N. J., 620 pp.

Zitko, $V ., 1980$. Metabolism and distribution by aquatic animals. In: The handbook of environmental chemistry. Ed. by O. Hutzinger. Springer, Berlin, 2A, 221-228. 